Originally published as:

Leendertz, F.H., Lankester, F., Guislain, P., Néel, C., Drori, O., Dupain, J., Speede, S., Reed, P., Wolfe, N., Loul, S., Mpoudi-Ngole, E., Peeters, M., Boesch, C., Pauli, G., Ellerbrok, H., Leroy, E.M.

Anthrax in western and Central African great apes

(2006) American Journal of Primatology, 68 (9), pp. 928-933.

DOI: 10.1002/ajp.20298

The definitive version is available at: http://onlinelibrary.wiley.com/ 


\title{
Anthrax in Western and Central African Great Apes
}

\author{
Fabian H. Leendertz ${ }^{1,2,3,{ }^{*}}$, Felix Lankester, ${ }^{4, *}$, Patrick Guislain ${ }^{5}$, Cécile Néel ${ }^{10,11}$, Ofir Drori ${ }^{6}$, \\ Jef Dupain $^{5}$, Sheri Speede ${ }^{7}$, Patricia Reed ${ }^{8}$, Nathan Wolfe ${ }^{9}$, Severin Loul ${ }^{10,11}$, E. Mpoudi- \\ Ngole $^{10,11}$, Martine Peeters ${ }^{10}$, Christophe Boesch ${ }^{3}$, Georg Pauli ${ }^{2}$, Heinz Ellerbrok ${ }^{2}$, Eric M. \\ Leroy $^{10,12}$ \\ ${ }^{1}$ Great Ape Health Monitoring Unit, c/o Max Planck Institute for Evolutionary Anthropology, Leipzig, Germany \\ ${ }^{2}$ Center for Biological Safety 1, Robert Koch Institute, Berlin, Germany \\ ${ }^{3}$ Max Planck Institute for Evolutionary Anthropology, Leipzig, Germany \\ ${ }^{4}$ Limbe Wildlife Centre, Limbe, Cameroon \\ ${ }^{5}$ Projet Grands Singes, Yaoundé, Cameroon, Royal Zoological Society of Antwerp, Antwerp, Netherlands \\ ${ }^{6}$ Last Great Ape Organisation, Yaoundé, Cameroon \\ ${ }^{7}$ In Defense of Animals-Africa, Belabo, Cameroon \\ ${ }^{8}$ Wildlife Conservation Society, Field Veterinary Program, New York, New York \\ ${ }^{9}$ Department of Epidemiology, Bloomberg School of Public Health, Johns Hopkins University, Baltimore, Maryland \\ ${ }^{10}$ Institut de Recherche et de Développement, Montpellier, France \\ ${ }^{11}$ PRESSICA, Yaoundé, Cameroon \\ ${ }^{12}$ Centre de Recherche Médicale de Franceville, Franceville, Gabon
}

${ }^{*}$ Correspondence to: Fabian H. Leendertz, Robert Koch Institute, ZBS 1, Nordufer 20, 13353 Berlin, Germany. E-mail: LeendertzF@rki.de

Fabian $\mathrm{H}$. Leendertz and Felix Lankester contributed equally to this work.

\begin{abstract}
During the period of December 2004 to January 2005, Bacillus anthracis killed three wild chimpanzees (Pan troglodytes troglodytes) and one gorilla (Gorilla gorilla gorilla) in a tropical forest in Cameroon. While this is the second anthrax outbreak in wild chimpanzees, this is the first case of anthrax in gorillas ever reported. The number of great apes in Central Africa is dramatically declining and the populations are seriously threatened by diseases, mainly Ebola. Nevertheless, a considerable number of deaths cannot be attributed to Ebola virus and remained unexplained. Our results show that diseases other than Ebola may also threaten wild great apes, and indicate that the role of anthrax in great ape mortality may have been underestimated. These results suggest that risk identification, assessment, and management for the survival of the last great apes should be performed with an open mind, since various pathogens with distinct characteristics in epidemiology and pathogenicity may impact the populations. An animal mortality monitoring network covering the entire African tropical forest, with the dual aims of preventing both great ape extinction and human disease outbreaks, will create necessary baseline data for such risk assessments and management plans.
\end{abstract}

\section{Introduction}

Ebola virus has had a devastating effect on the Central African great ape populations of Gabon and the Republic of Congo (RC) [Leroy et al., 2004; Walsh et al., 2003], where $80 \%$ of Africa's remaining gorillas and chimpanzees are found. Gorilla and chimpanzee densities are estimated to have fallen by at least 90\% between 1994 and 1996 throughout Minkebe Forest, which is located in northeastern Gabon close to the border with Cameroon [Huijbregts et al., 2003]. Likewise, great ape populations are estimated to have declined by up to $80 \%$ in the Gabon/RC border region between 2001 and 2003 [Leroy et al., 2004]. However, not all dead apes available for testing have tested positive for Ebola, raising the concerns that other pathogens may also be involved in this substantial die-off.

During the period of December 2004 and January 2005, three chimpanzees (Pan troglodytes troglodytes) and one gorilla (Gorilla gorilla gorilla) carcasses were recovered within a 35-km2 area at the northern border of the Dja Biosphere Reserve, a Cameroonian forest region adjacent to Minkebe Forest (Table I).

Bone and muscle samples were tested for various pathogens by the Great Ape Health Monitoring Unit (GAHMU) and the Centre International de Recherches Médicales de Franceville (CIRMF). In a highly sensitive and specific real-time PCR assay (for detailed methodology see Ellerbrok et al. [2002]), all 
four animals tested positive for the Bacillus anthracis-specific virulence genes cap and pag, as well as for the chromosomal rpoB gene.

\section{Materials and Methods}

Since mortality in wild great apes can be caused by a variety of pathogens, identification of these pathogens requires a broad approach, including analyses for the various pathogens that may have caused death. Since Ebola virus has had a major impact on the great apes of a nearby region, this pathogen was analyzed first, followed by a variety of other tests, including real-time PCR assays for B. anthracis, Orthopox viruses, Yersinia pestis, and Francisella tularensis, and a general screening for a broad spectrum of bacteria using a PCR based on the highly conserved 16S rDNA region of the bacterial genome, followed by cloning and sequencing.

\section{DNA and RNA Extraction and PCR}

For analyses at the Robert Koch Institute (RKI), bone samples were available from the gorilla and two of the chimpanzees, as well as muscle tissue from the third chimpanzee that was preserved in RNAlater (Qiagen, Hilden, Germany; Table I). The bones were cleaned and disinfected from the outside, and transferred into a new glove box for sample preparation. Bone marrow and the muscle sample were extracted and DNA was prepared with the DNeasy tissue kit (Qiagen). The samples were tested by real-time PCR for various pathogens, including B. anthracis, using three different real-time PCRs targeting the pag and capC genes encoded by plasmids $\mathrm{pXO} 1$ and $\mathrm{pXO} 2$, respectively, and the chromosomal rpoB gene (see Ellerbrok et al. [2002] for details). Plasmids pXO1 and pXO2 both have to be present in pathogenic B. anthracis [Ellerbrok et al., 2002; Hill et al., 2004; Koehler 2002]. They can therefore be used to differentiate virulent $B$. anthracis from apathogenic variants and the closelyrelated species B. cereus, B. thuringiensis, and B. megaterium [Ellerbrok et al., 2002]. Amplification was performed in two independent replicates for each sample.

All specimens for Ebola testing were taken and manipulated at the BSL4 laboratory of the Centre International de Recherches Médicales de Franceville (CIRMF) in Gabon, according to World Health Organization (WHO) guidelines on the screening of viral hemorrhagic fever agents in Africa. Total RNA was extracted from the bone marrow and the muscle sample from all four great ape samples available, first-strand cDNA was synthesized, and cDNA was amplified as previously described [Leroy et al., 2004]. The methods used to detect Ebola virus antigens and immunohistochemical staining were based on previously described procedures [Leroy et al., 2004].

\section{Results}

All samples from the three chimpanzees and one gorilla analyzed at the RKI were clearly positive for anthrax in all three PCR assays, and negative for the other pathogens analyzed, including Ebola, which was tested at the CIRMF, Gabon. It is worth noting that since 2001 samples of muscle and skin tissue from 15 other well-preserved great ape carcasses have been tested for Ebola at the CIRMF. Of these, nine animals tested positive, and all of these were discovered during the human Ebola outbreaks that occurred between 2001 and 2003 [World Health Organization, 2004]. Six wellpreserved carcasses tested negative for Ebola. However, none of the Ebola-negative samples tested at CIRMF remain for further investigation, and therefore could not be tested for $\mathrm{B}$. anthracis.

These findings indicate that in addition to Ebola, anthrax accounts for mortalities in wild great apes. Additionally, there remain a number of unexplained deaths for which respiratory diseases, measles, or other pathogens may be responsible [Leendertz et al., in press; Wolfe et al., 1998] and the cause of death has not been diagnosed. 


\section{Discussion}

This is the second reported outbreak of anthrax in wild chimpanzees following the original report of anthrax in chimpanzees from the Taï Forest in Côte d'Ivoire [Leendertz et al., 2004]. Furthermore, this represents the first recorded case of anthrax in gorillas, and it is the first time that anthrax has been detected simultaneously in Central African chimpanzees and gorillas. The detection of anthrax in chimpanzees and gorillas from two different regions of African tropical rainforest, a habitat with extremely low visibility, may indicate that a large number of victims have not yet been discovered. This suggests that the role of anthrax in great ape mortality may have been underestimated.

B. anthracis is not normally transmitted from one animal to another; the epidemiology of infection is usually linked to a particular source [e.g., Beatty et al., 2003; Lindeque \& Turnbull, 1994], such as contaminated ground (grass) that is consumed by grazing animals, contaminated water, or the meat of other anthrax victims consumed by scavengers and humans. In addition, there are two significant presentations of anthrax: cutaneous and respiratory [Jensen et al., 2003]. Briefly, cutaneous anthrax is a less lethal form that results from infections in open wounds and has a local manifestation. Respiratory anthrax is highly lethal and has recently garnered attention because of bioterrorist acts, an accidental release from a bio-weapons facility, and accidents in the leather industry [Abramova et al., 1993; Jackson et al., 1998; Lane et al., 2001]. This form has not been described in natural settings.

The epidemiology shows that in contrast to diseases that spread easily from one animal to another (e.g., Ebola virus, measles, respiratory diseases, and many others) anthrax does not have the potential to cause progressive outbreaks. However, areas that are largely contaminated with spores of B. anthracis may still cause significant concern to the local human population because spores of B. anthracis are highly resistant in the environment and can survive hundreds of years in the ground [Jensen et al., 2003].

To avoid contamination of areas that have no history of anthrax outbreaks, an appropriate preventative risk management plan is required. This may include hygienic barriers around the protected area, including the disinfection of tires before vehicles enter the protected area. Because of the frequency of anthrax outbreaks involving domestic ruminants, farming close to park boundaries should be prohibited. Additionally, a detailed monitoring program is required to assess the presence of the pathogen in protected areas.

Such monitoring is most practical when it is based on systematic mortality monitoring and the collection of samples from carcasses. In addition, noninvasive sampling from live animals (feces and urine) can be performed and used for specific analyses. A major constraint hampering the systematic collection of samples from carcasses and live animals is that in remote areas refrigeration is frequently unavailable, and thus cool chains cannot be maintained. However, recently developed methods enable samples to be stored without special requirements, such as cooling [Leendertz et al., in press]. These methods could open up new possibilities for epidemiological studies, even in areas with no infrastructure, and may significantly enhance our understanding of mortality in wildlife [Leendertz et al., in press].

Because of the physiological and genetic similarities between humans and great apes, human pathogens can be easily transmitted to great apes, resulting in their death [Ferber, 2000; Wallis, 2000; Woodford et al., 2002]. Therefore, collected samples should be tested for a variety of pathogens, including human pathogens, especially in areas where great apes are found in close proximity to human beings (e.g., great ape research camps and tourism sites).

The results of such a broad pathogen monitoring program may allow the assessment of risk factors and form the basis of an appropriate risk-assessment plan.

Existing countermeasures can then be reevaluated while taking into account the epidemiology of all of the important pathogens found in a certain region, including pathogens that may pose a substantial threat to both wildlife and human beings (e.g., Ebola and anthrax). 


\section{Acknowledgements}

We thank the government of Cameroon (especially MINFOF, MINSANTE, and MINRESI) for its longterm support. The carcasses were discovered during field work funded by the L.S.B. Leakey Foundation and the King Leopold III Fund for Nature Exploration and Conservation. The GAHMU Task Force is supported by the Woodland Park Zoo (Seattle, Washington) and the Cleveland Metroparks Zoo (Cleveland, Ohio).

\section{References}

Abramova FA, Grinberg LM, Yampolskaya OV, Walker DH. 1993. Pathology of inhalational anthrax in 42 cases from the Sverdlovsk outbreak of 1979. Proc Natl Acad Sci USA 90:2291-2294.

Beatty ME, Ashford DA, Griffin PM, Tauxe RV, Sobel J. 2003. Gastrointestinal anthrax: review of the literature. Arch Intern Med 163:2527-2531.

Ellerbrok H, Nattermann H, Özel M, Beutin L, Appel B, Pauli G. 2002. Rapid and sensitive identification of pathogenic and apathogenic Bacillus anthracis by real-time PCR. FEMS Microbiol Lett 214:51-59.

Ferber D. 2000. Primatology. Human diseases threaten great apes. Science 289:1277-1278.

Hill KK, Ticknor LO, Okinaka RT, Asay M, Blair H, Bliss KA, Laker M, Pardington PE, Richardson AP, Tonks M, Beecher DJ, Kemp JD, Kolsto AB, Wong AC, Keim P, Jackson PJ. 2004. Fluorescent amplified fragment length polymorphism analysis of Bacillus anthracis, Bacillus cereus, and Bacillus thuringiensis isolates. Appl Environ Microbiol 70:1068-1080.

Huijbregts B, De Wachter P, Ndong Obiang S, Akou Ella M. 2003. Ebola and the decline of gorilla Gorilla gorilla and chimpanzee Pan troglodytes populations in Minkebe forest, north-eastern Gabon. Oryx 37:437-443.

Jackson PJ, Hugh-Jones ME, Adair DM, Green G, Hill KK, Kuske CR, Grinberg LM, Abramova FA, Keim P. 1998. PCR analysis of tissue samples from the 1979 Sverdlovsk anthrax victims: the presence of multiple Bacillus anthracis strains in different victims. Proc Natl Acad Sci USA 95: 12241229.

Jensen GB, Hansen BM, Eilenberg J, Mahillon J. 2003. The hidden lifestyles of Bacillus cereus and relatives. Environ Microbiol 5: 631-640.

Koehler TM. 2002. Bacillus anthracis genetics and virulence gene regulation. Curr Top Microbiol Immunol 271:143-164.

Lane HC, Montagne JL, Fauci AS. 2001. Bioterrorism: a clear and present danger. Nat Med 7:12711273.

Leendertz FH, Ellerbrok H, Boesch C, Couacy-Hymann E, Matz-Rensing K, Hakenbeck R, Bergmann C, Abaza P, Junglen S, Moebius Y, Vigilant L, Formenty P, Pauli G. 2004. Anthrax kills wild chimpanzees in a tropical rainforest. Nature 430: 451-452.

Leendertz FH, Pauli G, Ellerbrok H, Maetz- Rensing K, Boardman W, Jensen SA, Junglen S, Boesch C. Systematic disease monitoring in wild great apes. Biol Conserv Special Issue (in press).

Leroy EM, Rouquet P, Formenty P, Souquiere S, Kilbourne A, Froment JM, Bermejo M, Smit S, Karesh W, Swanepoel R, Zaki SR, Rollin PE. 2004. Multiple Ebola virus transmission events and rapid decline of Central African wildlife. Science 303: 387-390.

Lindeque PM, Turnbull PC. 1994. Ecology and epidemiology of anthrax in the Etosha National Park, Namibia. Onderstepoort J Vet Res 61:71-83.

Wallis J. 2000. Prevention of disease transmission in primate conservation. Ann N Y Acad

Sci 916:691-693. Walsh PD, Abernethy KA, Bermejo M, Beyers R, De Wachter P, Akou ME, Huijbregts B, Mambounga DI, Toham AK, Kilbourn AM, Lahm SA, Latour S, Maisels F, Mbina C,

Mihindou Y, Obiang SN, Effa EN, Starkey MP, Telfer P, Thibault M, Tutin CE, White LJ, Wilkie DS. 2003. Catastrophic ape decline in western equatorial Africa. Nature 422:611-614.

Wolfe ND, Escalante AA, Karesh WB, Kilbourn A, Spielman A, Lal AA. 1998. Wild primate populations in emerging infectious disease research: the missing link? Emerg Infect Dis 4:149-158.

Woodford MH, Butynski TM, Karesh WB. 2002. Habituating the great apes: the disease risk. Oryx 36:153-160.

World Health Organization. 2004. Ebola haemorrhagic fever-fact sheet revised in May 2004. Wkly Epidemiol Rec 79:435-439. 


\section{Tables}

Table 1 Carcasses Found at the Northern Periphery of the Dja Reserve Cameroon*

\begin{tabular}{|c|c|c|c|c|c|c|}
\hline \multirow{2}{*}{$\begin{array}{l}\text { Species/sample } \\
\text { number }\end{array}$} & \multirow{2}{*}{$\begin{array}{l}\text { Date found/ } \\
\text { place }\end{array}$} & \multirow[b]{2}{*}{ Sample analysed } & \multicolumn{2}{|c|}{ Results } & \multicolumn{2}{|c|}{ Anthrax } \\
\hline & & & Ebola & pag & $\operatorname{cap} \mathrm{C}$ & rpo B \\
\hline Gorilla/1 & 19.Dec. '04/n.d & Mandible & Neg & Pos & Pos & Pos \\
\hline Chimpanzee/2 & $\begin{array}{l}\text { 09. Dec. '04/ } \\
03^{\circ} 22^{\prime} 28^{\prime} ’ \mathrm{~N}, \\
13^{\circ} 08^{\prime} 08^{\prime \prime} \mathrm{E}\end{array}$ & Scull, scapula & Neg & Pos & Pos & Pos \\
\hline Chimpanzee/3 & $\begin{array}{l}\text { 13. Dec. '04/ } \\
03^{\circ} 22^{\prime} 03^{\prime \prime} \mathrm{N}, \\
13^{\circ} 08^{\prime} 02^{\prime \prime} \mathrm{E}\end{array}$ & Tibia & Neg & Pos & Pos & Pos \\
\hline Chimpanzee/4 & $\begin{array}{l}\text { 09. Jan. '05/ } \\
03^{\circ} 26^{\prime} 48^{\prime \prime} \mathrm{N} \text {, } \\
13^{\circ} 09^{\prime} 05^{\prime \prime} \mathrm{E}\end{array}$ & Muscle (in RNAlater) & Neg & Pos & Pos & Pos \\
\hline
\end{tabular}

*Corresponding samples tested negative for Ebola by the CIRMF. All samples were also negative for Orthopox virus, Yersinia, Francisella and others. n.d, no data, only rough description available; Pos, positive; Neg, negative results from PCR testing. 